\title{
BANK RISK LEVEL AND BANK CAPITAL : THE CASE OF THE INDONESIAN BANKING SECTOR ${ }^{1}$
}

\author{
Muyanja Ssenyonga ${ }^{2}$ and Dibyo Prabowo ${ }^{3}$ \\ Gadjah Mada University
}

\begin{abstract}
ABSTRAK
Artikel ini menganalisis hubungan antara risiko bank dan modal. Dengan mengunakan analisis 3SLS penelitian inimenemukan adanya hubungan negatif antara tingkat risiko dan modal sektor perbankan. Tingkat aktiva sektor perbankan menunjukkan hubungan positif dengan risiko bank, sama halnya dengan krisis moneter 1997. Tingkat kurs rupiah terhadap dollar dan pasiva dalam mata uang asing menunjukkan adanya hubungan negatif dengan tingkat modal perbankan. Implikasi kebijakan adalah perlunya meningkatkan kepatuhan bank pada prinsip kehati-hatian, penambahan modal bank, dan pengawasan transaksi bank yang dilakukan dalam mata uang asing
\end{abstract}

Kata Kunci: Risk exposure; capital; risk tolerance level; default; moral hazard

\section{INTRODUCTION}

The road to full-fledged recovery of the Indonesian banking sector in the aftermath of the devastating 1997 economic crisis continues to be elusive, at least in some respects. The decision by Bank Indonesia to follow The Federal reserve in making a reversal from an interest cutting regime (loose monetary policy) to an interest rate hiking regime over recent months has rekindled fears of yet another growth-sapping monetary policy regime to come with its attendant credit contraction, slower investment, lower output, and rising unemployment. Inflation that reached 7.5 percent by March, 2005, had a year later, March, 2006, soared to 15.74 percent $^{4}$; interest

1 Without any intention to derive unduly from the impeccable reputation of the personality, the researcher is indebted to Adiningsih for the useful and constructive criticisms made on the draft of the article. Otherwise all errors and omissions constitute the responsibility of the authors.

2 Is a research fellow at the Center for Asia and Pacific Studies, Gadjah Mada University, Yogyakarta.

3 Is a Professor of Economics, Faculty of Economics, Gadjah Mada University, Yogyakarta

4 Inflation stood at 17.92 in February, 2006 rate has followed suit, and now hovers around 12.75 percent, an indication that a spate of higher interest rate hikes continues to be a strong possibility. Higher Bank Indonesia interest rates send signals to bankers that both deposit and credit rates have to go up. Deposit rates have to move along with inflation if savers' interest in putting their money in banks is to be maintained, while credit rates have be higher than deposit rates to enable banks pay depositors and earn some profit margin as compensation for conducting financial intermediation. The most quoted of all indicators of bank lack of sound health, the ratio of non performing loans over total loans disbursed has already shown signs of increasing, after experiencing a downward trend over the past few years. The bank sector NPL has risen from 5.8 in percent December 2004 , to 8.3 percent by December, $2005^{5}$.

\footnotetext{
5 State-owned banks have even higher NPL than their private sector counterparts( for instance Bank Mandiri and Bank BNI are reported by The Jakarta post, April, 20, 2006 to experience $26.7 \%$ and $13.7 \%$ NPL ratios , respectively reported to be having NPL banks due to legal constraints they face in selling NPL loans (which
} 
Basing on the above indicators, one would argue that there isn't a better wakeup call for the banking sector to fasten the harness, for even worse times to come.

Worrying though the above signs are, a number of indicators show that the long term trend of the Indonesian banking system is moving toward a gradual, albeit, slow path to recovery. Banking sector recovery is underpinned by increasingly solid, stable, and robust performance of the economy which, registered 5.6 percent growth in 2005 higher than 5.1 posted in 2004 , and is projected to surpass the 6 percent mark $^{6}$ this year (2006).

Sound, stable and sustainable economic growth is vital for sound bank performance. Evidence of this is discernible from the level of bank deposits, which has steadily increased over the past few years, a factor that attests to the resurgence of public confidence in the financial sector in general, and in the banking sector in particular (bank deposits experienced a 17.1 percent increase in 2005 increasing from Rp. 963.1 trillion (2004) to Rp.1,127.9 trillion (2005); rising credit level of credit disbursement which was Rp. 595.1 trillion (2004) and surged by 22.70 percent to Rp.730.2 trillion (2005); the level of bank assets is upwards being valued at Rp.1272.3 trillion (2004), experienced an increase of 15.52 percent to reach Rp. 1469.8 percent (2005)). This is an indication that the foundation of the banking sector, severely rocked by 1997 economic crisis, is slowly but surely re-establishing itself as one of the prime pillars of the national economy.

Additionally, one of the most vital indicators of bank intermediation, is the Loan to Deposit Ratio (LDR). The LDR had by December 2005 reached 64.7 percent, a good percentage points higher that 61.9 percent registered in 2004. The decline in year to year

are state assets) to third parties, an obstacle that private banks do not encounter.

${ }^{6}$ The national budget projected growth rates for $2006 / 2007$ is 5.3-6.3 percent
Non Performing Loans Ratio (NPL), is another indicator of banking sector recovery. The NPL has shown a down ward trend in the year to year trend and reached 5.8 percent in December, 2004 (if control of the short term effects of the petroleum price hike policy adopted by the government in April and October $2005^{7}$ ).

Encouraging though the above indicators, there a shadow continues to linger over banking sector total recovery. And factors pointing toward that direction aren't difficult to find, either. One such key factor is the slow intermediation level registered by the banking sector, which though happened to reach the 64.7 percent in $2005^{8}$, has shown signs of waning as tight monetary policy measures undertaken by Bank Indonesia (prime interest rate, raising the bank reserve ratio, sucking liquidity out of the economy through open market operations and fine tuning, have had the effect of increasing the cost of funds for banks and lenders, over the last quarter, which are ringing bells of raising credit risk.

The Loan to Deposit Ratio (LDR), which is a good measure of bank intermediation, continues to be shy of 100 percent, which is an indication that despite accumulating large volumes of deposits from customers, banks

\footnotetext{
7 The current (by December 2005) NPL ratio is 8.3 percent, consequent upon high inflation rate (17.92 percent) which came head on heels of a two-phase petroleum oil hike. Counter measures against high inflation has led to the reversal of the spate of interest cuts undertaken by Bank Indonesia prior to October 2005 , raising prime interest rate in a series of phases to the current level of 12.75. Such a level of prime interest rates has induced banks to raise deposit rates and lending rates, which has had adverse impact on loan repayment

851 percent of bank credit (2005) went to small and medium scale enterprises, an increase from 48.5 percent registered the previous year (2004). This was partly due to bank reorientation from concentrating lending to the corporate sector to SMEs but also as a response to demands by the central bank and the government for banks to channel more credit to the sub sector. Many banks had to write down and even completely write off credit disbursed to SMEs prior to the 1997 crisis due to the high default rate
} 
continue to shy away from indulging in fullscale lending to the non-financial sector (Corsetti, 1998). The level of bank capital is still considered to be a far cry from that expected of a sound banking sector, a fact that underlies Bank Indonesia efforts to raise capital requirements to a minimum of $\mathrm{Rp} .80$ billion by 2007 . It is undeniable that banks have not yet fully recovered from the 'severe' scars caused by the 1997 economic crisis which led to immense "writing-downs" and "writing-offs" of NPL, which significantly reduced bank capital. One should not ignore the fact that the rate of return on bank assets has also fallen from 3.5 percent (2004) to 2.6 percent (2005): an indication of increasing risk on bank portfolios, higher cost of funding sources due to rising interest rate, and decreasing return on investment, among other causes. Falling bank profitability is also shown by decrease in net interest margin from 6.3 percent (2004) to 6.2 percent (2005).

This is coupled by insufficient capital contribution made by bank shareholders (Lindgren et al., 1996). The woes commercial banks continue to suffer are not only attributed to shocks caused by the 1997 economic crisis, strong as they were, but the seeds of a shaky, risk riddled banking sector can be traced as far back as 1988, some would even say earlier than June 1983. Financial liberation has been linked to increasing banking sector risk by many researchers (Diaz-Alejandro, 1985; Fry, 1995; Cole \& Slade, 1998; Kaminsky \& Reinhart, 1998). In October, 1988, came the Pakto 1988 banking reforms which were to fundamentally alter all aspects of the Indonesian banking system, ranging from the players, operations, management, to bank products and services. Interest rate on deposits and credit was deregulated, which in effect reduced control over banks funds mobilization and disbursement (read investment). Local banks were allowed to open new branches, provided pre-conditions were fulfilled. Banks incorporated abroad were allowed to open local branches, which by so doing intensified competition for banking customers in the national economy.

Doubtless increased competition, spawned news ways of winning customers from rivals, some of which were woefully imprudent. As local interest rates rose, commercial banks begun to go offshore to countries offering funds at lower interest rates. This was because despite high cost of funds, the high business confidence in the economy, meant that potential risk of borrowing high cost funds was discounted considerably, especially as the economy was registering annual growth rates in the $7.0-7.8$ percent range, domestic currency under tight managed float regime, inflation under control, and national budget deficit proscribed, even if that was more in form than in substance (the balanced budget stipulation). Banks indulged in offering all manner of incentives to attract additional customers. This ranged from lotteries, straight presents upon opening new accounts, and so on.

The 1988 deregulation package allowed national private banks to open and operate branches nationwide, a privilege that had hitherto been the monopoly of state owned banks. Limitations on foreign bank operations were loosened significantly, allowing them to operate branches in more large cities in Indonesia. Many banks begun indulging in foreign currency operations and business, allowing customers to open up accounts denominated in foreign currency units, borrowing from abroad and offshore loans denominated in foreign currency, and extending loans denominated in foreign currency as well. The open capital account policy adopted by Indonesia during the 1970s made this even easier. Such operations were conducted with a minimum of risk management policies in place, which were measures "not totally unjustifiable" under the then buoyant economic conditions the Indonesian economy enjoyed. 
No doubt, additional product/service lines did not only increase sources of operational cost and income, but increased sources of risk for banks that had barely had any sound risk management programs in place. Moreover, as competition in the credit market stiffened, banks loosened their credit policy, which led to the channeling of credit to borrowers without sound business plans, creditworthiness, and management acumen. Not a few banks extended loans to affiliate companies above the limits set by the law, an act that increased the possibility of waiving stringent credit extension policies. Increased number of banks and branches were not accompanied by enhanced human resources development in bank management as well as in bank supervision, which recipe for banking operations running under conditions of unsound, un prudential banking practices, which were brought to light by the 1997 economic crisis (Chellilah, 1993; Brewer et al., 1996; Fukuchi, 1995).

However, the banking sector did have some risk management policies. For instance banks have had to comply with prudential banking principles by among other things adjusting bank capital and provisioning in line with investment risk, limit their risk exposure, limits set on affiliated lending, and tighter lending policies imposed.

Nonetheless, it was not until the 1997 economic crisis exposed the magnitude of bank the malaise that even more stringent measures were put in place. This took the forms of over-the-limit credit extension to single debtors as well as affiliates, large overhang of un-hedged offshore borrowing sparked by interest differentials between domestic and international money markets, and large-scale fraud involving bank management and shareholders with controlling interests, among others.

Various measures have been taken to plug the holes in the Indonesian banking system. The banking law No. 10, 1998 has been the landmark in reshaping the new bank architecture to be in line with sound banking principles. The law overhauled the banking system, by among other things setting up more stringent measures for starting bank operations (higher authorized capital levels, permitting only personalities with integrity and good track record in banking to become bank managers and owners, enjoining banks to put in place credible credit policies, and risk management programs. The law also widened the scope of bank activities widened, and henceforth included not only conventional banking activities of taking deposits and lending (intermediation), and information provision, but also extended to underwriting securities, issuing securities, factoring, and so on. The diversification of bank activities meant increased source of bank risk, which is why banks are obliged to adopt even more sound risk management policies.

That is not to say banks have not been obliged to have risk management programs in place. Bank Indonesia, for instance, obliges banks to have in place asset risk management programs, which are line with compliance with prudential banking policies. Bank Indonesia law No. 23, 1999, by stating its independence from the intervention of external interests, government interests inclusive, is yet another milestone in shaping the new banking system. The law stipulates that Bank Indonesia will no longer guarantee subsidized credit disbursed by commercial banks to lenders, which epitomizes vestiges of a policy once adopted by the government during periods of financial repression to support priority sectors.

Henceforth banks have to take ultimate responsibility for loans they disburse, meaning that any problems in repayment will bear heavily on the capital adequacy ratio of the respective bank. Banks have to pay premiums of between 0.1 and 0.5 percent of deposits accumulated to the national deposits insurance agency, depending on the degree of their asset risk. Moreover, banks have to contend with the 
maximum limit set on the amount of depositors' funds guaranteed by national deposits insurance agency. The government has in effect from March 2006, revoked the blanket guarantee of all depositors' funds in general banks, which has been in effect since 1998 to a maximum of Rp. 5 billions per single client/debtor. This no doubt creates yet another source of risk, which banks must deal with.

Bank Indonesia has made remarkable strides in strengthening the Indonesian banking system to enable it stand up to the formidable challenges of a fully liberalized financial services era, to come into effect in the not too distant future. In this vein, Bank Indonesia has set in motion a phased implementation of Basel II Principles between 2007 and 2010, which obliges banks augment their equity to Rp. 80 billion, categorizing banks into limited activities banks, focused banks, national banks and international banks depending on capital; beefing up bank infrastructure through the establishment of depository insurance agency, delimitation functions among national depository insurance agency, Bank Indonesia and Ministry of Finance concretized by the formation of forum for financial system stability; and the establishing bank risk management certification, which rates and ranks bank risk management programs.( Bank Indonesia, 2006).

Bank Indonesia has issued regulations aimed at encouraging and bolstering risk management policies in general banks. Such regulations include Bank Indonesia regulation No. 8/4/PBI/2006 on implementation of good governance in banks. The regulation obliges banks adopt principles of transparency, accountability, responsibility, independence, and fairness in the conduct of their activities; regulation No, 8/2/PBI/2006 on the evaluation of productive assets, which in effect obliges banks to adopt uniform classification of productive assets arising from extending funds the same debtor or project, which means consolidation of risk arising from such investment; and regulation No. 8/6/PBI/2006 that obliges banks to consolidate risks that arise from subsidiaries and associated companies through individual and consolidating financial reporting, identification, measuring, and controlling risks by adopting both individual and consolidated reporting and provisioning (Bank Indonesia, 2006). The aforementioned efforts were bolstered by strengthening, intensifying and focusing bank supervision in line with best practices 25 Basel core principles. To leave no room for a repeat of past bank fraud, imprudence, and impropriety, Bank Indonesia established a panel of experts drawn from various fields to handle bank regulation.

In anticipation of a flurry of legal action involving general banks and third parties in the aftermath of the establishment of national depositors' insurance agency, accompanied by a limitation of state guarantee of depositors' funds at banks, Bank Indonesia regulation No. 8/5/PBI/2006 on bank mediation outlines the modalities under which such risks can be tackled by banks.

Be that as it may, the catalogue of potential risks for banks, if anything shows strong signs of increasing. The drivers of bank risk, among others, include macroeconomic risk, arising changes in macroeconomic fundamentals that range from $s$ rise in interest rate (stands at 12.75 percent today), inflation (17.92 percent), fluctuating exchange rate (from Rp.9,831 ${ }^{9}$ December 2005 to Rp.8980/US\$ today), and rising budget deficit (government deficit rose from 0.7 percent of GDP (2004) to 0.9 percent of GDP (2005)). Austere macroeconomic fundamentals have sent other sectors jittering as evidenced by the effect of a fall in consumption expenditure (from a contribution of 4.9 percent (2004) to 4.45 percent (2005) to GDP growth. Such a trend persists in the first quarter of 2006 , discernible in the drop to

\footnotetext{
9 Rupiah /US\$ exchange rate rose as high as Rp.10,830 during the last quarter on 2005 before it recovered at Rp. 9,831 on December 30, 2005
} 
Rp.204.24 trillion in consumption expenditure registered in January from Rp.206.69 trillion posted in December, 2005. Sluggish consumption expenditure undermines investment expenditure recovery. Investment expenditure for December 2005 is lower than that registered in the previous month, Rp.134.40 trillion, and Rp.134.40 trillion, respectively. The downward trend in investment expenditure continues January and February, 2006, with Rp.132.37 trillion and Rp.131.31 trillion in investment expenditure made, respectively. Contraction in consumption expenditure has had adverse effects on bank profits. This is reflected by an 18.3 percent reduction in profits posted by Indonesian banks from Rp.29.46 trillion in 2004 to Rp.24.9 trillion 2005. It is a trend that is likely to persist until the middle of the second quarter, 2006 (Kompas, February 24, 2006).

Banks continue to face other forms of risks which encompass potential risk from entrance of new players and products in the financial sector which stiffens competition, technological innovations that make slow adopters laggards in products, procedures, and services development and delivery, globalization, which virtually opens the hitherto captive clientele to a variety of choices with respect to financial institutions in general and among banks in particular to use in the conduct of services, products and services available; and unavoidable spate of regulations which banks must comply with in the process of conducting their operations.

Besides conventional risks emanating from non performing loans arising from corporate credit disbursement, foreign exchange operations, banks are becoming increasingly exposed to credit card risk which has been attributed to efforts by banks to increase their respective shares of the credit market holders' market. Indeed increase in credit card transactions is a reflection of the general trend the national economy has followed since investment suffered what has become a protracted decline. The country's economic growth has been driven by consumption, both private and government ${ }^{10}$. The rising NPL on credit card transactions is attributed to various measures taken by banks to expand the number of credit card holders. Such measures range from transfer balance on credit cards from one bank to the other, transfer credit card balance to savings account, providing cash-back offers that entail the exemption of the owner from paying a certain percentage of some transactions, to awarding points per transaction paid using the card, which are then converted into discounts on new credit card transactions, among others

Non performing credit to card holders rises with rising interest rates, all other factors constant. Another contributory factor to high credit card transactions default is the reality that new card issuing made go to those who already have credit cards issued by other banks or non bank credit card issuers. This is as much reflected in statistics on credit holders and number of credit issuance. While the number of credit cards issued by December 2005 was 6.5 million, the number of credit card holders was less than half than number at 3 million. That translates into an average of 2 credit cards per card holder (The Jakarta Post, 2006).

Technology risk continues to be another formidable source of risk for banks that do not update their operations with the latest front and back office service technology, payment systems technology, and accounting and information system technology, will have to relinquish their market share to early technology adopters. Commercial banks in developing countries in general and Indonesia in particular often have to contend with another form of risk, which arises from being forced to serve as agents of development. This is apparent in Bank Indonesia law No. 7/3,

\footnotetext{
${ }^{10}$ Consumption contributed 73.7 percent of GDP growth in 2005, while investment made modest 22 percent contribution to GDP in the same period
} 
2005 on maximum credit amount extended by banks. The law gives exception to state banks in their extension of credit to projects that are considered of immense social benefit, such as infrastructure to exceed the maximum level of credit extended by any given bank to a single debtor from 20 percent to o 30 percent of bank capital (Kompas, Saturday 8, 2006). Funding long term, state sponsored projects, is likely to widen the mismatch between bank liabilities, which are generally short and medium term, and bank assets. This constitutes a serious source of risk, albeit a forced one for banks to bear.

Bank risk arising from bank mismanagement which is manifested in fraud continues to bedevil the banking industry, which is attests to the persistence of serious flaws the failures in bank management, especially credit policy and risk management areas, shortcomings in prevailing onsite and offsite bank supervision mechanisms, continuing state intervention, albeit covert, in the operations of state banks, and the lackluster implementation of prudential practices already in place.

It is for this reason that Bank Indonesia intends to raise the capital adequacy ratio from 8 percent in accordance with Basel 1988 to 12 percent which is accordance with Basel 2003 arrangement, by 2007. It is in light of such conditions under which banks operate which continues to be characterized by high risk vulnerability, that induced the researcher to attempt to analyze the relationship between bank risk and capital a bank has, which is aimed at identifying empirically, factors responsible for bank risk, and the effect such risk has on the level of bank equity. The second section tackles literature review and theoretical framework, while section three describes the methodology used. Section four presents research findings, while section five presents a discussion of research findings. Section six draws conclusion, and the last section presents policy implications.

\section{LITERATURE REVIEW AND THEORE- TICAL FRAMEWORK}

\section{The Relationship Between Bank Capital and Bank Risk}

One of the most important measures of bank soundness is the size of its capital. Banks with a good capital base stems a bank from insolvency as losses are met from equity without irrevocably undermining bank performance. Moreover, bank equity provides the second line defense against expected risk which arises from such conventional sources as default on credit disbursed, shortage of funding sources, interest rate changes, exchange rate fluctuations, and fraud (from both internal and external sources), among others. Equity has a non linear relationship with risk for given a certain portfolio risk, the risk of insolvency falls as capital increases. However, additional capital is shown to have minor effect on risk (McCullough, 1981). It is because of this that the effectiveness and efficiency of modern bank management owes a lot to the extent to which management ensures a match between bank capital and assets risk in a bank's investment portfolio.

Bank supervision has for long advocated for a link between a bank's types of risk manifested in its investment activities and its capital. Bank's must avail larger capital amounts for investments that are more risky than others. The main parameter used by central banks in the conduct of their supervision of bank operations use the CAMEL framework, which was initiated by central banks' banker Basel based bank for international settlements. Known as prudential banking principles, the CAMEL ${ }^{11}$ framework

\footnotetext{
${ }^{11}$ Bank performance is rated on a 1 to 5 scale with respect to capital adequacy, asset quality, management quality, earnings performance, and liquidity. A score of 1 on each of the five criteria indicates best performance, while a score of 5 is an indication of worst performance on the respective criterion. Evaluation is also made on a composite basis, that the overall performance on all the five CAMEL criteria. A composite score of 1 or 2 by a
} 
ranks bank soundness on the basis of the quality of risk-weighted equity, assets, management, earnings performance and liquidity (Hefferman, 1998).

According to Shrieves \& Dahl (1994) a positive relationship exists between change in equity and level of risk on commercial bank assets. Such a relationship is found in banks with capital adequacy ratios are either above or below that stipulated by bank supervisory body. The implication is that banks tend to adjust bank capital in accordance with asset risk, rather than increase investment in risky assets without taking account of inherent risk levels.

Financial risk is the possibility that the outcome of an action or event could bring up adverse impacts in forms of loss in earnings, constraints on ability to meet business objectives, inhibit bank's ability to take on opportunities that would boost its performance, among others. Banks face a variety of risks which encompass credit, market, liquidity, operational, regulatory, and reputation risks. Credit risk arises from the potential that debtor may either be unwilling to repay borrowed funds, or unable to repay his obligations resulting into economic loss to the bank (State Bank of Pakistan, 2003).

Market risk arises from the adverse effects that movements in market rates and prices such as interest rates, foreign exchange rates, equity prices, credit spreads, and commodity prices, among others, have on the value of a bank's on and off balance sheet positions. Liquidity risk is the potential loss to a bank that arises from either its inability to meet its obligations or to fund increase in assets as they fall due without incurring unacceptable cost or losses. The bank

bank is considered satisfactory, while composite scores of between 3 and 4 by a bank, implies the ban in question has to face additional supervision by the authority responsible for bank supervision. Banks with composite scores of 4 or 5 are in for close monitoring, and a score of 5 is considered by supervisors that the bank has a high probabability of failure (Hefferman, 1998: 233) doesn't have sufficient liquid assets to meet its obligations, meaning that it has to resort to market sources.

For a low liquidity bank, obtaining funds from the market comes at a premium which depends on its illiquidity, the liquidity of the market, and the track record of the bank in question. Operational risk arises from inadequate or failed internal processes, people, and systems, or from external events. Such risk is often associated with human error, system failures, inadequate procedures and controls, inadequate information systems, technology glitches, breaches in internal controls, fraud, unforeseen catastrophes.

In accordance with the mean variance school of thought, risk averters maximize utility by choosing higher leverage levels than equity levels. This means that risk averters avoid funding bank operations using equity preferring the use of funds from foreign sources. The corollary to this is that there is a negative relationship between asset risk level and equity level. The above relationship is attributed to several factors, which among others; include taking advantage of fixed deposit insurance guarantee imposed by the central bank on deposits received by banks. By investing deposits into high risk assets, bank management maximizes the bank value (Diamond \& Dybzig, 1986). Bank management has the opportunity to attract as many bank deposits as possible, which are then invested in high risk assets that in turn earn high return.

However, there are factors that inhibit a bank from earning high return on very risky investments. Such factors include the increase in costs banks must pay arising from having very risky assets, bankrupt costs or liquidation charges, which increase with the risk of assets. This implies that banks have an incentive to adjust equity level with the level of risk in their investments. The corollary to that is that there is a positive relationship between the level of risk contained in bank assets and level of equity. 
Managing bank risk has become one of the most important determinants of a bank's success, measured by its market position. Risk management is the ability to measure, monitor, control, stem risks comprehensively as a decisive parameter for strategic positioning. Thus, the degree to which a bank manages the variety of risk it faces, determines not only its success in today's world, but its very survival as a going concern.

Commercial banks are also obliged to comply with monetary authority rules that call for increasing capital level in line with increasing level of investment risk. Banks then have to pay cost in terms of additional capital if the level of risk contained in their assets/investments is considered by bank supervisors to experience an increase.

This is what is known in banking circles as prudential banking principles. Banks have to comply with prudential banking principles by for instance matching the level of assets on bank balance sheets with consonant bank equity (Flannery, 1989). Bank managers having specialized skills are assumed to be against experiencing bankruptcy of banks under their control as they find it difficult to transfer their skills to other trades or business sectors. This implies that bank managers are risk averters in this context. Thus it is in the interest of bank managers to increase the level of bank equity/capital to be in line with bank asset risk. In other words, bank managers tend to reduce the level of risk on assets given bank capital level.

\section{Hypotheses}

1. Bank risk level has a negative relationship with bank equity

2. The level of bank equity has a negative relationship with the level of bank asset risk

\section{METHODOLOGY}

The research analysis used secondary data, which were obtained from the central bureau of statistics, Bank Indonesia, and Kompas newspaper. The research covers a period between 1980-2002.

The research used the Shrieves \& Dahl (1992) model to analyze the relationship between bank asset risk and bank equity as outlined hereunder:

$$
\begin{aligned}
\Delta \mathrm{CAP}= & \alpha_{0}+\alpha_{1} \text { LNASSET }+\alpha_{2} \mathrm{REG}+ \\
& \alpha_{3} \Delta \mathrm{NPL}+\varepsilon \\
\Delta \mathrm{NPL}= & \beta_{0}+\beta_{1} \Delta \mathrm{CAP}+\beta_{3} \text { LNASSET }+ \\
& \varepsilon
\end{aligned}
$$

Where $\triangle \mathrm{CAP}$ represents change in level of bank equity/capital; LNASSET is natural logarithm of bank assets; $\triangle \mathrm{NPL}$ is change in the level of non performing loans, (percentage of loans that are above 90 days over total bank loans in all banks; REG is the dummy to proxy the impact of government regulation on bank capital. The complete model comprises three equations with the level of bank risk as determined by institutional risk rating agencies, as dependent variable, and bank capital, natural logarithm of bank assets, and dummy to represent government policy, as independent variables.

Upon making the simultaneous test, Shrieves \& Dahl (1992) found that that was interdependence between level of bank risk and level of bank capital. So the relationship between the two variables runs either way from bank asset risk to bank capital level and from the level of bank capital to bank asset risk. There is thus simultaneity in the relationship between the two variables. This is the underlying reason why the analysis used two least squares model 2SLS. This is because of the model ability to remove serial correlation existing between dependent and independent variables. The model used in this research was based on that developed by Shrieves \& Dahl (1992) but opted for 3SLS technique due to strong residual covariance. The results obtained using the model, were then compared with those obtained from the cross section model. However, to analyze the same variables using both time series and cross section models, some changes had to be made 
on data on commercial banks available. The changes made pertaining to data made are shown hereunder. The model which was eventually used in analyzing the data consisted of two equations as appears in the model above.

However, due to the difficulty encountered by the researcher to obtain data on commercial banks and from an independent bank rating agency. Secondly, considering the fact that data on almost all variables on all banks were difficult to obtain, save just a few with readily available data, the researcher had to resort to using aggregate data on the banking sector as these were readily available in several Bank Indonesia and Central Bureau of Statistics Publications, and IMF International Finance Statistics. Due to the difficulty encountered in obtaining data on the level of non performing loans NPL in the banking sector, the variable was replaced by the total volume of Bank Indonesia loans extended to banks ${ }^{12}$ .Commercial banks generally avoid borrowing funds from the central bank not only because of the high cost of such borrowing, but also such banks end up being categorized as holding risky portfolios ${ }^{13}$.

Another variable used as a proxy for NPL is the level of liability denominated in foreign currency in the banking sector. The two variables were used interchangeably during the analysis to identify which of the two better represents banking sector risk than the other. The analysis tools used 3SLS as strong residual covariance was evident.

The model used in model II is as follows:

\footnotetext{
${ }^{12}$ The assumption is that commercial banks only resort to borrowing funds from the central bank under conditions of low liquidity both internally and from the interbank market. Banks that borrow funds from the central bank face the danger of being categorized as more risky than others and therefore called upon to add more loan provisioning and capital

${ }^{13}$ Commercial banks often utilize the lender of the last resort facility provided by central banks to overcome serious liquidity shortage. The problem is that recipient banks suffer from downgrading of the healthy state, which automatically increases their ranks on the risk rating index.
}

$$
\begin{gathered}
\text { LBKEQUI }=\alpha_{0}+\alpha_{11} \text { LBKASS }+ \\
\alpha_{12} \text { BREG }+\alpha_{13} \text { CRIS }+ \\
\alpha_{14} \text { LBLBI }+\varepsilon \\
\text { LBLBI }=\beta_{0}+\beta_{21} \text { LBKEQUI }+ \\
\beta_{22} \text { LBKASS }+\beta_{23} \text { CRIS }+\varepsilon
\end{gathered}
$$

Whereby:

LBKEQUI is the banking sector capital in year $\mathrm{t}$; is total loans extended by Bank Indonesia (central bank) to the banking sector in year t; LBKASS is total assets in the banking sector in year $t$; BREG is the dummy variable indicating when the adoption of prudential banking principles came into effect in Indonesia in 1992 zero (0) represents years before 1992, and one (1) for year 1992 and beyond; CRIS is dummy variable representing the impact of the economic crisis that occurred in 1997 on bank capital and risk. The variables assume the value zero (0) for years before 1997, while 1997 and beyond assume the value of one (1). LBFRLIB is the total banking sector to foreign creditors; LEXRATE is the exchange rate of local currency one dollar US; (LCAR is the natural logarithm of the capital adequacy ratio while NPLR is the natural logarithm of the non performing loans on balance sheets of all commercial banks, as shown in Table 1).

\section{Analysis Procedure}

E-Views 3 analysis tool was in transforming data and running the model. Data was tested for normality and for stationarity by observing unit root results. Unit root test used Dickey-Fuller unit root test. The Ramsey test was used to examine model specification. Transformation of data into natural logarithm was made using E-Views 3 analysis tool. Interpretation of results used 5 percent significance error to identify the coefficients that were significant. Coefficients with $\mathrm{p}$-value lower than 0.05 were identified as significant, while those with higher p-value were identified as insignificant. 


\section{PRESENTATION OF RESEARCH FINDINGS}

Table 1. Cross section analysis results of the relationship between bank equity and bank risk

\section{Model 1}

Dependent Variable: LCAR

\begin{tabular}{|l|c|l|l|l|}
\hline \multicolumn{1}{|c|}{ Variable } & Coefficient & Std. Error & t-Statistic & Prob. \\
\hline \multicolumn{1}{|c|}{ LNPLR } & -0.04 & 0.112143 & -0.356605 & 0.7288 \\
BREG & -0.75 & 0.341794 & -2.196828 & 0.0527 \\
\multicolumn{1}{|c|}{ LBKASS } & $0.21^{* * *}$ & 0.016843 & 12.59345 & 0.0000 \\
\hline R-squared & 0.293924 & \multicolumn{2}{|l|}{ Mean dependent var } & 2.968554 \\
Adjusted R-squared & 0.152709 & S.D. dependent var & 0.735689 \\
S.E. of regression & 0.677190 & Akaike info criterion & 0.257444 \\
Sum squared resid & 4.585860 & Schwarz criterion & 0.387817 \\
Log likelihood & -11.67338 & F-statistic & 2.081391 \\
Durbin-Watson stat & 2.088491 & Prob(F-statistic) & 0.005492 \\
\hline
\end{tabular}

*** significant at 95 percent, and 99 percent confidence levels, respectively

Table 2. Three-stage least squares 3SLS analysis results of the relationship between equity and commercial bank risk (Model 1)

\begin{tabular}{|c|c|c|c|c|}
\hline Variable & Coefficient & Std. Error & t-Statistic & Prob. \\
\hline$\alpha_{1}$ & $2.095051 * * *$ & 0.409380 & 5.117623 & 0.0000 \\
\hline$\alpha_{2}$ & 0.169463 & 0.227511 & 0.744855 & 0.4639 \\
\hline$\alpha_{3}$ & $2.899835 * * *$ & 0.837062 & 3.464300 & 0.0021 \\
\hline$\alpha_{4}$ & $-1.711592 * * *$ & 0.516169 & -3.315954 & 0.0030 \\
\hline$(\mathrm{AR})$ & 0.044632 & 0.143655 & 0.310689 & 0.7588 \\
\hline$\beta_{1}$ & -0.012518 & 0.238680 & -0.052446 & 0.9586 \\
\hline$\beta_{2}$ & 0.003488 & 0.371406 & 0.009390 & 0.9926 \\
\hline$\beta_{3}$ & $1.222010 * * *$ & 0.271385 & 4.502872 & 0.0002 \\
\hline$\beta_{4}$ & 0.678967 & 0.373308 & 1.818786 & 0.0820 \\
\hline$\beta_{5}$ & 0.390410 & 0.208872 & 1.869136 & 0.0744 \\
\hline (AR) & $0.996514 * * *$ & 0.031554 & 31.58164 & 0.0000 \\
\hline \multicolumn{5}{|c|}{ Equation: LBKEQUI $=\alpha_{1}$ LBKASS $+\alpha_{2}$ BREG $+\alpha_{3}$ CRIS $+\alpha_{4}$ LBLBI $+[$ AR $]$} \\
\hline R-squared & 0.923511 & \multirow{4}{*}{\multicolumn{2}{|c|}{$\begin{array}{l}\text { Mean dependent var } \\
\text { S.D. dependent var } \\
\text { Sum squared resid }\end{array}$}} & 8.926576 \\
\hline Adjusted R-squared & 0.895697 & & & 1.144449 \\
\hline S.E. of regression & 0.369612 & & & 1.502740 \\
\hline Durbin-Watson stat & 2.060064 & & & \\
\hline \multicolumn{5}{|c|}{ Equation: LBLBI $=\beta_{1}$ LBKEQUI $+\beta_{2}$ LEXRATE $+\beta_{3}$ CRIS $+\beta_{4}$ LBKASS $+\beta_{5}$ LBRES $+[$ AR } \\
\hline R-squared & 0.888968 & \multirow{4}{*}{\multicolumn{2}{|c|}{$\begin{array}{l}\text { Mean dependent var } \\
\text { S.D. dependent var } \\
\text { Sum squared resid }\end{array}$}} & 9.322579 \\
\hline Adjusted R-squared & 0.842705 & & & 0.718648 \\
\hline S.E. of regression & 0.285019 & & & 0.974832 \\
\hline Durbin-Watson stat & 2.090055 & & & \\
\hline
\end{tabular}

*** significant at 95 percent, and 99 percent confidence levels, respectively 
Table 3 . Three stage least square analysis Results of the relationship between bank equity and bank risk (Model 3)

\begin{tabular}{|c|c|c|c|c|}
\hline Variable & Coefficient & Std. Error & t-Statistic & Prob. \\
\hline$\alpha_{1}$ LBKASS & 0.140500 & 0.112710 & 1.246558 & 0.2233 \\
\hline$\alpha_{2}$ LBLBI & -0.109780 & 0.098303 & -1.116759 & 0.2739 \\
\hline ( AR) & $1.028684 * * *$ & 0.004726 & 217.6573 & 0.0000 \\
\hline$\beta_{1}$ LBKEQUI & $-0.388538 * * *$ & 0.112149 & -3.464473 & 0.0018 \\
\hline$\beta_{2}$ LBKASS & $1.071422 * * *$ & 0.085315 & 12.55849 & 0.0000 \\
\hline$\beta_{3}$ CRIS & 0.122489 & 0.208741 & 0.586796 & 0.5622 \\
\hline$(\mathrm{AR})$ & 0.052701 & 0.136815 & 0.385200 & 0.7031 \\
\hline \multicolumn{5}{|c|}{ Equation: LBKEQUI $=\alpha_{1}$ LBKASS $+\alpha_{2}$ LBLBI $+[\mathrm{AR}]$} \\
\hline R-squared & 0.989435 & \multirow{4}{*}{\multicolumn{2}{|c|}{$\begin{array}{l}\text { Mean dependent var } \\
\text { S.D. dependent var } \\
\text { Sum squared resid }\end{array}$}} & 8.936453 \\
\hline Adjusted R-squared & 0.988026 & & & 1.293163 \\
\hline S.E. of regression & 0.141503 & & & 0.300345 \\
\hline Durbin-Watson stat & 1.896782 & & & \\
\hline \multirow{2}{*}{\multicolumn{5}{|c|}{$\begin{array}{l}\text { Equation: LBLBI }=\beta_{1} \text { LBKEQUI }+\beta_{2} \text { LBKASS }+\beta_{3} \text { CRIS }+[\mathrm{AR}] \\
\text { Observations: } 16\end{array}$}} \\
\hline & & & & \\
\hline R-squared & 0.828534 & \multirow{4}{*}{\multicolumn{2}{|c|}{$\begin{array}{l}\text { Mean dependent var } \\
\text { S.D. dependent var } \\
\text { Sum squared resid }\end{array}$}} & 9.197137 \\
\hline Adjusted R-squared & 0.785668 & & & 0.458628 \\
\hline S.E. of regression & 0.212326 & & & 0.540990 \\
\hline Durbin-Watson stat & 2.050409 & & & \\
\hline
\end{tabular}

*** significant at 95 percent, and 99 percent confidence levels, respectively

\section{DISCUSSION OF RESEARCH FINDINGS}

Analysis results obtained from cross section data, 2000 shows the existence of a negative relationship between the Non Performing Loans Ratio (NPL), and Capital Adequacy Ratio (CAR). This implies that banks which have problematic/risky assets do not have Capital Adequacy Ratio that is in line with such asset risk levels. This is due to the existence of a safety valve in forms of government blanket guarantee of bank liability and bank recapitalization. Banks used to have bad quality assets which meant that they had higher non performing loans levels than their capital adequacy ratios. Total bank assets show a positive relationship with capital adequacy ratio, which is an indication that banks have large volumes of poor quality assets with the consequence that they are obliged to augment bank equity in order for banks to continue complying with mandatory minimum capital adequacy ratios as set by Bank Indonesia .

Research results exhibit the expected negative relationship between banking sector risk -1.71 (-3.32) as represented by Bank Indonesia liquidity credits disbursed to banks (BLBI), and bank assets. Banking system assets are found to have a positive influence on bank equity and liquidity disbursed by the central bank 2.1 (5.12), and 0.68 (1.8), respectively (table 2). Equity level in the banking system has a negative influence on the level of Bank Indonesia liquidity support disbursed by Bank Indonesia -.39, (-3.46) (Table 2 and Table 3).

The positive relationship between level of bank assets and bank equity is proof of the success achieved by the prudential banking policy as stipulated by the central bank. By linking bank asset risk with equity level, prudential banking principles, reduce adverse 
selection and moral hazard. The dummy variable BREG shows a positive but insignificant magnitude. Most assets of commercial banks constitute loans that carry high default risk, which is why banks should have high capital levels from which deduction are made in case potential default risk becomes actual default risk. Bank capital serves as a cushion that absorbs loan defaults which is a normal occurrence for commercial banks. So according to data obtained from Bank Indonesia and The National Bureau of Statistics, the Indonesian banking system has succeeded in implementing prudential banking principles, which took effect in 1992, and augmented in 1994 and 1998 (through the Banking Law No. 10, 1998).

Research results indicate that large banks in terms of assets received equally large volume of Bank Indonesia liquidity support. There are two reasons to explain such a relationship. One explanation is that banks with huge assets are too big to fail, hence governments, through the central bank, try the best they can to prevent bankruptcy. The justification often advanced by the government in bailing out large banks, is the attempt to prevent systemic risk that can ensue from bankruptcy and collapse of a major lender in an economy. Allowing a big lender to go under, tantamount to sending a bad signal to depositors that their money is not safe, which can induce runs on all banks as public confidence in banking system wanes. The effect of a full-scale bank run is arguably more costly than bailing out large, albeit troubled lenders. Another explanation is most assets in commercial banks constituted of poor quality assets, in other words risky, which meant that banks had to put up equally large capital levels commensurate with the high risk. The latter reason is given more weight given the fact that large banks were found to have large volumes of non performing loans, especially in the aftermath of the convulsive 1997 economic crisis. Many banks also has had large volume of loans known as green accounts, which were in reality in default but reported as performing loans to avoid falling into lower risk ranking.

Research findings also show the existence of a negative relationship between bank liability owed to foreign creditors and the level of bank capital/equity. The relationship is caused by the effect of that exchange rate of the local currency IDR against hard currency such as US dollar, on bank assets and liquidity. An appreciation of the Rupiah increases the value of bank assets as well as bank liability denominated in the local currency, while a depreciation of the local currency lowers the value of bank assets and also bank liability denominated in local currency (Table 2 and Table 3). However, depreciation of the local currency, though lowers liability denominated in local currency, also has the negative effect of lowering the value of bank assets denominated in Rupiah as well as increasing the value of liability denominated in foreign currency.

The economic crisis that hit Indonesia and other East Asian economies from mid 1997, increased bank risk, which made it imperative for Bank Indonesia to supplement bank liquidity by extending liquidity support (see the crisis dummy in the two equations in table 2). Bank liquidity support was aimed at reducing the impact of the economic shock on the Indonesian banking system, and by so doing, preventing the economy from descending into even deeper doldrums. The 1997 economic crisis adversely affected the level of bank capital both in the short term and long term. It was in order to sterilize the economy from even worse effects that induced the government to inject Rp. 154 trillion into banks which took the form of state bonds to keep the banking system afloat by increasing equity. This is attested by the CRIS dummy in equation I in Table 2, which shows a positive and significant value. 


\section{CONCLUSION}

Basing on research findings, the level of bank risk, proxied by Bank Indonesia liquidity support has a negative influence on bank capital. This is because banks, which receive liquidity support from the central bank have their asset portfolio performance down graded , an indication of high risk. Bank performance took nosedive during and after the 1997 economic crisis, which is why Bank Indonesia liquidity support increased significantly (see CRIS dummy in equation 2 in Bable 2). The level of bank assets has a positive influence on the level of Bank Indonesia liquidity support.

Bank transactions denominated in foreign currency, were found to have a negative influence on bank capital level due to high potential risk. The factor of risk became the more important on the advent of the 1997 economic crisis as illustrated in the second equation in Table 2 above. The magnitude of the EXRATE variable (IDR per US\$) increases in the wake of the 1997 economic crisis.

The impact of the 1997 economic crisis on bank performance took the form of increasing the risk banks face in their operations especially with regard to liabilities denominated in foreign currency. High risk made government intervention imperative which came in form of bank recapitalization to mitigate the impact of the crisis on the entire economy.

The implementation of prudential banking principles commenced some time back in 1992. Nonetheless, as research results indicate, it is still a long way for all banks to conduct all their operations in accordance with such principles, which should change bank management orientation from risk-taking to risk averse.

\section{POLICY IMPLICATIONS}

There is need for increasing (read intensifying) bank supervision to ensure all banks comply with prudential principles in the conduct of their operations. This should discourage banks from investing in high risk investments, without augmenting bank capital, as is prescribed by law. The gradual rolling back of government sponsored blanket guarantee of bank assets, and demanding banks to pay premium to the national deposit insurance agency in accordance with the level of risk of assets in bank portfolio are two right steps in the right direction. Bank Indonesia 's intention to focus on a bank's major source of risk in its regular supervision exercise, if implemented, should prevent blanket categorization of bank risk, which will augur well for more effective supervision and bank asset management (The Jakarta Post, Monday, March 27, 2006).

In order to enhance bank performance, measures should be taken to ensure that bank management puts in place and implements standard and flexible risk management policies and programs that in consonance with bank activities. This will ensure that such programs will be in line with the type and level of risks banks face, which are reflected in the types of activities a bank engages in. Such risk management policies should be underpinned by sound and universally proven risk management models. As the main source of risk commercial banks face is in form of credit risk, more measures should be taken in that direction. Measures that should be taken, among others, include setting up credit risk management committee/section in the bank, which should be responsible for implementing credit risk level set by the bank management. The committee should assess borrower risk profile, measures to quantify such risk, determine whether the risk level is in line with the risk level set by bank management, communicate to all sections about bank risk profile, ways of mitigating such risks, and sanctions awaiting those who violate standards set. Credit risk monitoring should be regularly done to ensure bank risk is within the tolerance levels set by top management. 
There is no effective risk management program that can succeed without the support of top management. This is because the ultimate responsibility of bank performance is with top management under the supervision of the board of directors. They set the risk profile they deem appropriate for the bank, appoint personnel that ensures stipulations on risk level are maintained as well as putting in place incentive packages for those whose activities help to reduce bank risk, and sanctions for those who violate them. They also provide human, material, and financial resources that facilitate the execution of an effective risk management program possible. This is much in line with the new approach adopted by bank for international settlements that emphasizes individual banks to identify risk profile they have and design risk management program that best reduce even eliminate risks they face.

Top management is also vital in ensuring the introduction, instilling, and maintenance of a risk control culture in the bank. This should be reflected, among others, in policies, processes, procedures in place to report risks that occur and those likely to occur, in the course of conducting bank businesses with and wloutside the organization, mitigate risks, and feasibility of alternative risk limitation and control strategies Of course such efforts should be under the observation and supervision of bank supervisory bodies.

Bank supervision must be made more effective by for instance increasing the regularity of on-site and off site supervisory services, combining bank rating systems using comprehensive bank risk assessment systems, with financial ratio and peer group analysis systems and statistical models. The vital importance of commercial banks in developing economies means that while bank management and directors may have their role in determining risk tolerance levels and designing appropriate risk management strategies and programs enhanced, central banks /bank supervisory agencies must ensure bank risk tolerance levels and strategies taken to mitigate them are commensurate with internal standards (Sahajwala \& Van Den Bergh, 2000).

Now time for a caveat. The recommendations made are based on the results of the research analysis made. Research analysis can not stand on its own without data that formed the backbone of it. Besides, the statistical tool used, data used in the analysis played a vital role in influencing the empirical results attained herein. Thus, the findings made here are as good as the data that was used in reaching the results.

\section{REFERENCE}

Bank Indonesia, 2006. Laporan Perekonomian Indonesia, 2005.

BPS, Indikator Ekonomi. Several editions

Brewer, E. III., W.E. Jackson III, and T.S. Mondschean. 1996. “ Risk, Regulation, and S\& L Diversification into Nontraditional Assets". Journal of Banking and Finance 20(4): 723-744

Cole D.C., and B.T.Slade, 1998. "The Crises and financial sector reform". Asean Economic Bulletin 15(3): 338-346

Corsetti, G., 1998. "Interpreting the Asian Crisis: Open Issues in Theory and Policy". Asian Development Review 16(2): 18-63

Chelliah, J.R. 1993. "Financial and Fiscal Reforms in Asian Countries". Asian Development Review 11(2): 47-71

Diamond, D.W. dan P.H.Dybvig, 1986. "Banking theory, deposit Insurance and bank regulation". Journal of Business 59: 55-67

Diaz-Alejandro.C. 1985. " Goodbye Financial repression, Hello financial crash". Journal of Development Economics 19(1-2): 1-24.

Flannery, M.J., 1989. “Capital regulation and insured banks' choice of individual loan default risks". Journal of Monetary Economics 24: 235-258 
Fukuchi T., 1995. "Liberalization Effect in Financially Repressed Economy: The Case of Indonesia, 1982-1990". The Developing Economies 33(3): 271-309

Fry, M.J. 1995. Money, Interest, and Banking in Economic Development, Second edition, Johns Hopkins University Press

Hefferman, S., 1998. Modern Banking in Theory and Practice, John Wiley and Sons

Kaminsky, G.C.,and C.M.Reinhart, 1998. "Financial Crises in Asia and Latin America: Then and Now". AEA papers, American Economic Review 88(2): 444448

Kompas, Saturday April 8, 2006. "BI Ajak Bank Tinjau BMBK: Perbankan Lebih Mengutamankan Kelayakan Usaha.” , February 24, 2006. “ Laba Bersih Bank Anjlok."

Lindgren, C., G. Garcia, and M. Isaal. 1996. Bank Soundness and Macroeconomic

Policy. The International Monetary Fund
McCullough, H.J., 1981. "Interest rate risk and capital adequacy for traditional banks and financial intermediaries" in Risk and capital adequacy in commercial banks, A National Bureau of Economic Research Monograph, The University of Chicago Press, S.J. Maisel as editor.

The Jakarta Post , Monday, March, 27, 2006. “ BI to Up supervision on banks, plan incentives". Business, 13.

, February 25, 2006. "Banks pull out all the stops to increase credit card use".

April 20, 2006. "Government Urged to Resolve NPL quagmire".

Sahajwala, R., and P. Van Den Bergh, 2000. “ Supervisory Risk Assessment and Early Warning Systems.” Working Papers, Basel Committee on Banking Supervision

State bank of Pakistan, 2003. "Guidelines for Commercial Banks and DFIs". Risk Management

http://www.sbp.org.pk/about/riskmgm.pdf http://www.bi.go.id/web/id/Peratura 